\title{
Selvmordsforebygging i Litauen
}

Ved N ils Petter Reinholdt

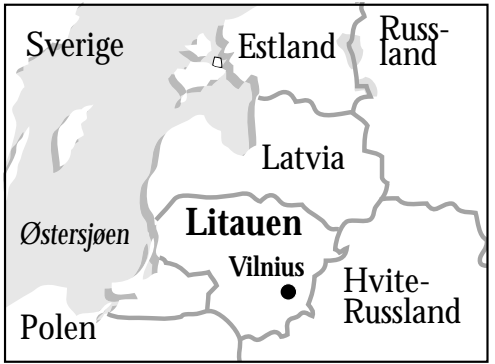

Det har skjedd store endringer i Litauen de siste årene. Det er blitt flere eldre. Fødselsraten er gått tilbake. Faerre personer gifter seg, og antall skilsmisser har økt. Forekomsten av psykiatriske lidelser og selvmord har vaert økende.

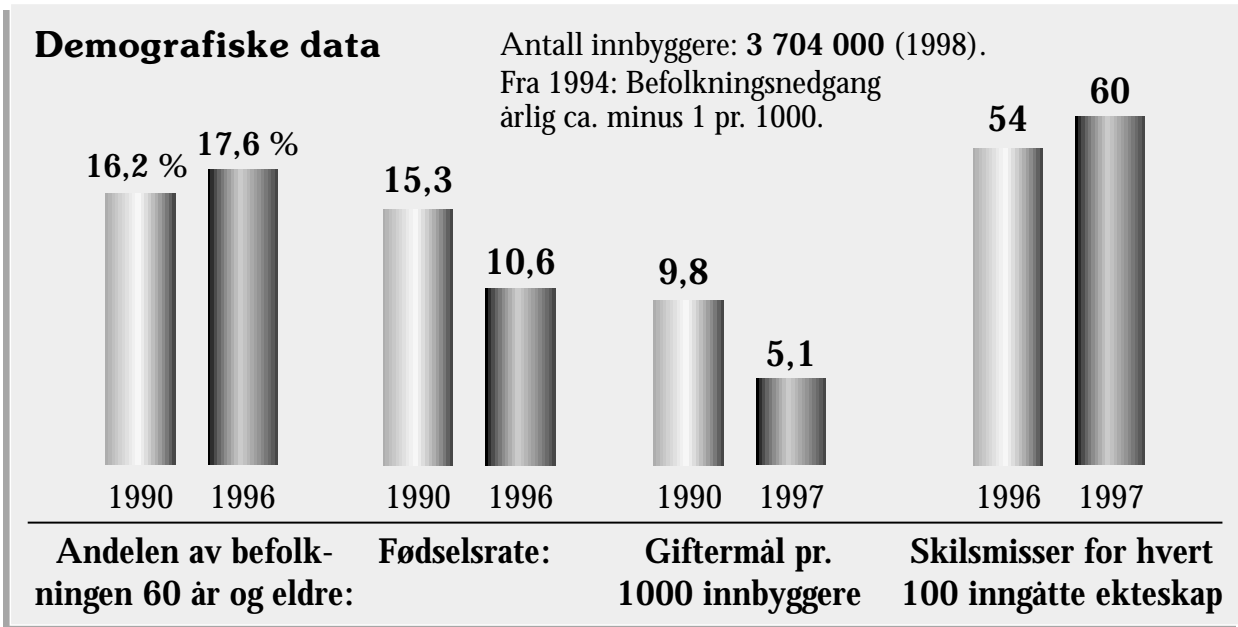

De demografiske dataene gir grobunn for betydelige sosiale og økonomiske problemer. Det er vanskelige levevilkår for befolkningen. En lærer og sykepleier tjener i snitt ca 100 U SD per måned, kun nok til å dekke husleien. Konsekvensen er at de fleste har 2-3 jobber. Det er videre ikke mulig å kunne leve som pensjonist av den statlige alderspensjonen. Klasseforskjellene er enorme med en stor gruppe mennesker som sliter betydelig. Problemene har forverret seg fra år til år etter frigjøringen fra Sovjet, og det "ropes" fra flere om at det var bedre før da man i det minste var sikret mat og arbeid. Per i dag er arbeidsløsheten minimum $10 \%$. Det naturlige land å eksportere varer til er Russland, men problemet er at landet ikke betaler for seg.

Behovet for helsetjenester er økende. Samtidig er det en relativt stor andel av befolkningen som på grunn av manglende sykeforsikring ikke har tilgang på disse.

\section{Selvmord i Litauen}

Forekomsten av psykiske lidelser er økende. I 1990 var det registrert 145688 mentalt syke (3.929 per 100 000). I 1997 var antallet steget til 155490 registrerte (4.194 per 100.000). A ntallet individer med alkoholrelaterte psykoser har vist en kraftig økning, stigende fra 12,3 i 1990 til 36,2 i 1995, og 45,6 pr. 100000 i 1997. Selvmordsraten steg fra 26,9 i 1990 til 46,8 pr. 100000 i 1995, noe som på det tidspunktet utgjorde den høyeste registrerte selvmordsraten i verden. En svært kraftig økning ble registrert i den mannlige delen av populasjonen, som steg fra 47,9 i 1990 til 87,5 i 1994. Den sterkeste økningen i selvmordsraten har funnet sted i de mindre sentrale områder av landet. I perioden 1995 til 1997 har det vært en svak reduksj on i selvmordsfrekvensen fra 46,8 til 44,8.

Den litauiske regjeringen har dette året, med bakgrunn i W H O s generelle strategier, utformet et statlig program for bedret helse. Blant målsetningene inngår en reduksjon av selvmordsraten til $25 \mathrm{pr}$. 100000 innen 2005.

\section{Nasjonal handlingsplan}

5.-6. mai i år ble det arrangert en konferanse om forebygging av selvmord $\mathrm{i}$ Vilnius, hovedstaden i Litauen. W H O finansierte konferansen og var representert med lederen for avdelingen for mental helse, dr. Jose M anoel Bertolote og professor N orman Sartorius fra U niversitetet i G eneve. Jeg presenterte der de erfaringene vi har gjort oss her i N orge gjennom $\mathrm{H}$ andlingsplan mot selvmord.

Konferansen ble vurdert som en svært viktig hendel se både fra faglig og administrativt hold i Litauen, og også fra W HOs side som pådrivere. Samtidig var det en betydelig reservasjon knyttet til den økonomiske situasjonen i Litauen og til det begren sede handlingsrommet dette skapte både faglig og administrativt.

I forbindelse med mitt innlegg inviterte jeg på vegne av $\mathrm{H}$ elsetilsynet en delegasjon fra Litauen til N orge for å møte sentrale aktører fra det norske handlingsprogrammet. Besøket fant sted 12.-15. oktober. Delegasjonen bestod av fire representanter ledet av den litauiske helse- ministeren Raimundas A lekna. I tillegg deltok Danute $G$ ailiene, psykolog, head of Department of C linical Psychology ved U niversitetet i Vilnius, O na Polukordiene, psykolog og president for Lithuanian A ssociation of Tel ephone Emergency Services, og O na Davidoniene, psykiater og direktør for State M ental $\mathrm{H}$ ealth Center i Litauen.

I løpet av de tre dagene delegasjonen tilbrakte i 0 slo, fikk de presentert sentrale erfaringer fra vår nasjonale handlingsplan mot selvmord. Presentasjoner ble fremført av representanter fra det nasjonale kompetansesenteret, de regionale ressursmiljøer og leder for den nyetablerte Landsforeningen for etterlatte ved selvmord. H elsetilsynet er svært takknemlig overfor alle som stilte opp, flere gjennom hele helgen, og som bidro til å gjøre besøket til en suksess.

Fredag kveld inviterte $\mathrm{H}$ elsetilsynet til representasjonsmiddag med deltakelse fra den politiske ledelsen i Sosial- og hel sedepartementet og ledelsen i H elsetilsynet.

Det ble tre svært hektiske dager i O slo for våre gjester fra Litauen. Ved siden av det faglige programmet, studiebesøk og sightseeing benyttet de nattetimene til drøftinger av strategi for sitt eget forebyggingsprogram.

Besøket var preget av en uformell atmosfære der rikelig med tid var avsatt til meningsutvekslinger. U nder drøftingene kom det frem at våre to nasjoner har mange likhetstrekk når det gjelder organisering og oppbygging av helsevesenet.

V åre litauiske gjester uttrykte dyptfølt takknemlighet for at besøket hadde kommet i stand, og var også svært tilfreds med utbyttet. M ed bakgrunn i politiske signaler og de relasjoner som nå er utviklet, tas det sikte på å videreutvikle samarbeidet med Litauen når det gjelder selvmordsforskning og -forebygging.

Vi har et moralsk ansvar til å yte hjelp både som et rikt, vestlig samfunn, og som ett av de første landene med et nasjonalt forebyggingsprogram mot selvmord.

$\mathrm{N}$ ils Petter Reinholdt er prosjektleder i $\mathrm{H}$ elsetilsynet 